\title{
SURFICIAL GEOLOGY AND MORPHOLOGY OF THE ALASKAN CENTRAL ARCTIC COASTAL PLAIN
}

\section{DIGITAL DATA ADDENDUM: ANALYTICAL DATA AND FIELD OBSERVATIONS FROM SURFICIAL GEOLOGY AND MORPHOLOGY OF THE ALASKAN CENTRAL ARCTIC COASTAL PLAIN}

Compiled by Michelle M. Gavel and Trent D. Hubbard

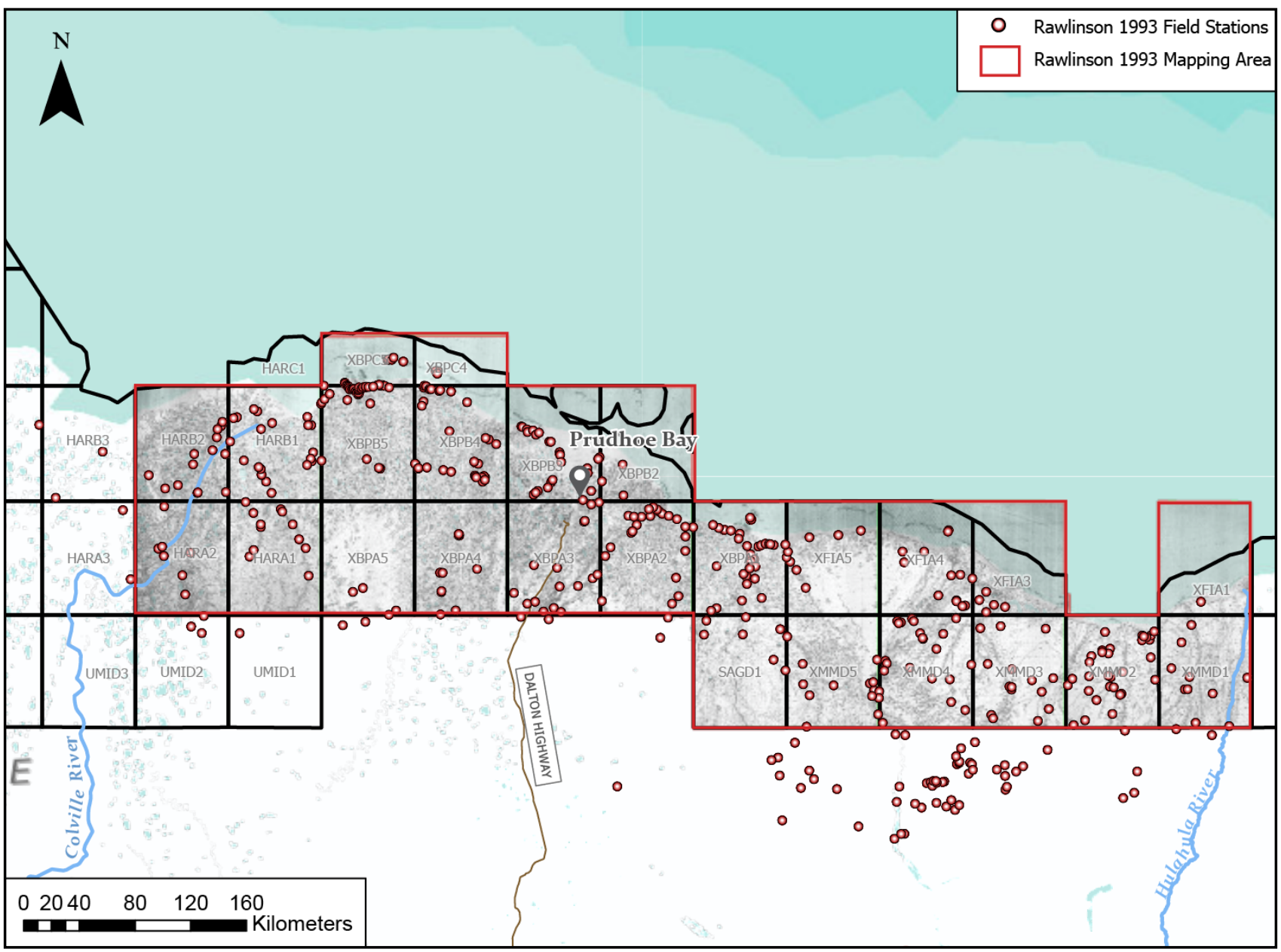

Field station locations and mapping area of Rawlinson (1993).

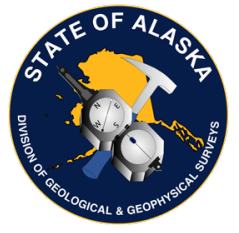

Published by STATE OF ALASKA DEPARTMENT OF NATURAL RESOURCES DIVISION OF GEOLOGICAL \& GEOPHYSICAL SURVEYS

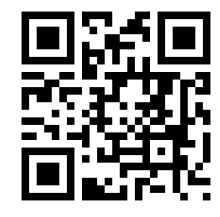



SURFICIAL GEOLOGY AND MORPHOLOGY OF THE ALASKAN CENTRAL ARCTIC COASTAL PLAIN

DIGITAL DATA ADDENDUM: ANALYTICAL DATA AND FIELD OBSERVATIONS FROM SURFICIAL GEOLOGY AND MORPHOLOGY OF THE ALASKAN CENTRAL ARCTIC COASTAL PLAIN

Compiled by Michelle M. Gavel and Trent D. Hubbard

Report of Investigation 93-1A

State of Alaska

Department of Natural Resources

Division of Geological \& Geophysical Surveys 


\section{STATE OF ALASKA}

Mike Dunleavy, Governor

\section{DEPARTMENT OF NATURAL RESOURCES}

Corri A. Feige, Commissioner

\section{DIVISION OF GEOLOGICAL \& GEOPHYSICAL SURVEYS}

Steve Masterman, State Geologist and Director

Publications produced by the Division of Geological \&

Geophysical Surveys (DGGS) are available for free download

from the DGGS website (dggs.alaska.gov). Publications on

hard-copy or digital media can be examined or purchased in

the Fairbanks office:

Alaska Division of Geological \& Geophysical Surveys

3354 College Rd., Fairbanks, Alaska 99709-3707

Phone: (907) 451-5010 Fax (907) 451-5050

dggspubs@alaska.gov|dggs.alaska.gov

\section{DGGS publications are also available at:}

Alaska State Library,

Historical Collections \& Talking Book Center

395 Whittier Street

Juneau, Alaska 99811

Alaska Resource Library and Information Services (ARLIS)

3150 C Street, Suite 100

Anchorage, Alaska 99503

\section{Suggested citation:}

Gavel, M.M., and Hubbard, T.D., comps., 2021, Analytical data and field observations from surficial geology and morphology of the Alaskan central Arctic Coastal Plain, 1981-1987, digital data addendum: Alaska Division of Geological \& Geophysical Surveys Report of Investigation 93-1A, 6 p.

https://doi.org/10.14509/30670
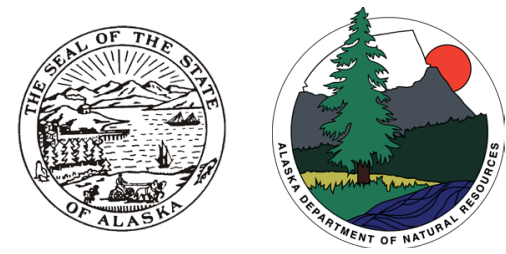


\section{SURFICIAL GEOLOGY AND MORPHOLOGY OF THE ALASKAN CENTRAL ARCTIC COASTAL PLAIN}

\section{DIGITAL DATA ADDENDUM: ANALYTICAL DATA AND FIELD OBSERVATIONS FROM SURFICIAL GEOLOGY AND MORPHOLOGY OF THE ALASKAN CENTRAL ARCTIC COASTAL PLAIN}

Compiled by Michelle M. Gavel ${ }^{1}$ and Trent D. Hubbard ${ }^{1}$

\section{INTRODUCTION}

From 1980-1987, scientists from the Alaska Division of Geological \& Geophysical Surveys (DGGS) conducted surficial geologic field investigations along Alaska's North Slope. The study area encompassed twenty-five 1:63,360-scale quadrangles between the Colville and Hulahula rivers. The geologic mapping, analytical data, interpretations, and measured sections resulting from these investigations were published in 1993 (Rawlinson, 1993). The geologic material samples and field notes from the project were preserved and curated in the Alaska Geologic Materials Center (GMC) and the DGGS Fairbanks office archives. In 2018, DGGS joined the Department of Natural Resources and the North Slope Borough Arctic Strategic Transportation and Resources (ASTAR) project. DGGS initiated significant work to use historic and newly acquired geologic and geospatial data to evaluate sand and gravel resources across the North Slope. To support this research, we scanned the 19801987 project field notes and reformatted published source data into digital files optimized for visualization and data analysis using ArcGIS software. Source data provides grain size, amino acid, thermoluminescence, carbon-14, palynology, microfossil, and wood identification measurements and observations. The analytical data tables and scanned project documentation associated with this release are available in digital format as comma-separated value (CSV) and portable document files (PDF). All files are available from the DGGS website https://doi.org/10.14509/30670.

\section{DATASET CONTENTS AND STRUCTURE}

This data release provides the following file collections:

- Scanned field notes, measured section diagrams, and laboratory observations. Files are organized by year and named to indicate content. File names for the measured section diagrams reflect the labels in the notes.

- Station and sample locations and identifiers, and analytical data tables for grain size, amino acid, thermoluminescence, carbon-14, palynology, microfossil, and wood identification. Figure 1 provides a list of tables and fields and indicates fields that can be used to link tables in a relational database. Each data table is accompanied by a data dictionary, which further describes the properties and values in each field. Figures 2 and 3 show the station locations for each data type.

Analytical data and field station locations were auto-read from the appendices using optical character recognition converted into tabular data files. We converted field station locations (Rawlinson, 1993, app. C) from degree-minute-second to decimal-degree notation. We then quality controlled

${ }^{1}$ Alaska Division of Geological \& Geophysical Surveys, 3354 College Rd., Fairbanks, Alaska 99709-3707. 
the exported field station locations using ArcGIS to visually compare them to corresponding plotted locality in scanned and georeferenced geologic maps (Rawlinson, 1986a, b, c, d, e; 1990; 1993). In the originating data, field station locations were visually approximated and recorded on aerial photographs or topographic maps. Offsets between the plotted and calculated points were generally in the range of 50-200 meters. In cases of larger offsets, we provide coordinates digitized from the scanned maps.

When possible, we used the lab correspondence, field notebooks, and other loose papers associated with Rawlinson's 1993 publication to augment or clarify the published summary data and to verify each sample's field station and sample numbering. Given the limitations of paper-based data management, the source data's consistency and completeness is impressive. For the most part, we were able to correlate field station numbers, sample numbers, map numbers, and reported depth to visualize and organize the data using a relational database hierarchy. However, achieving full referential integrity throughout the entire dataset would require discarding non-compliant data or assumptions unsupported by the field notes or published documentation. Due to these limitations, we decided to eliminate cross-table data dependencies and provide root sample metadata in each table (fig. 1).
Surplus sample material from the 19801987 field investigations is archived by the GMC in Anchorage, Alaska, and is available for public viewing on request. To facilitate GMC catalog searches, we provide sample and station numbers and auto-number identifiers standardized for consistency with the DGGS Geologic and Earth Resource Information Library of Alaska (GERILA) enterprise database (DGGS Staff and Papp, 2005).

\section{ACKNOWLEDGMENTS}

The State of Alaska funded this work as a component of the ASTAR project. We appreciate the hours of work conducted by our intern, Alex Terry, sorting and scanning the original field documents. The collective DGGS ASTAR work supports a collaborative effort between the North Slope Borough and the Department of Natural Resources to strengthen community infrastructure and facilitate access to arctic resources while enhancing the quality of life and economic opportunities for North Slope communities. It also provides valuable information for land-use management and planning decisions. Concurrent work to identify and catalog corresponding geologic materials samples was funded by the USGS National Geological and Geophysical Data Preservation Program (NGGDPP) awards G15AP00147 and G17AP00063. 


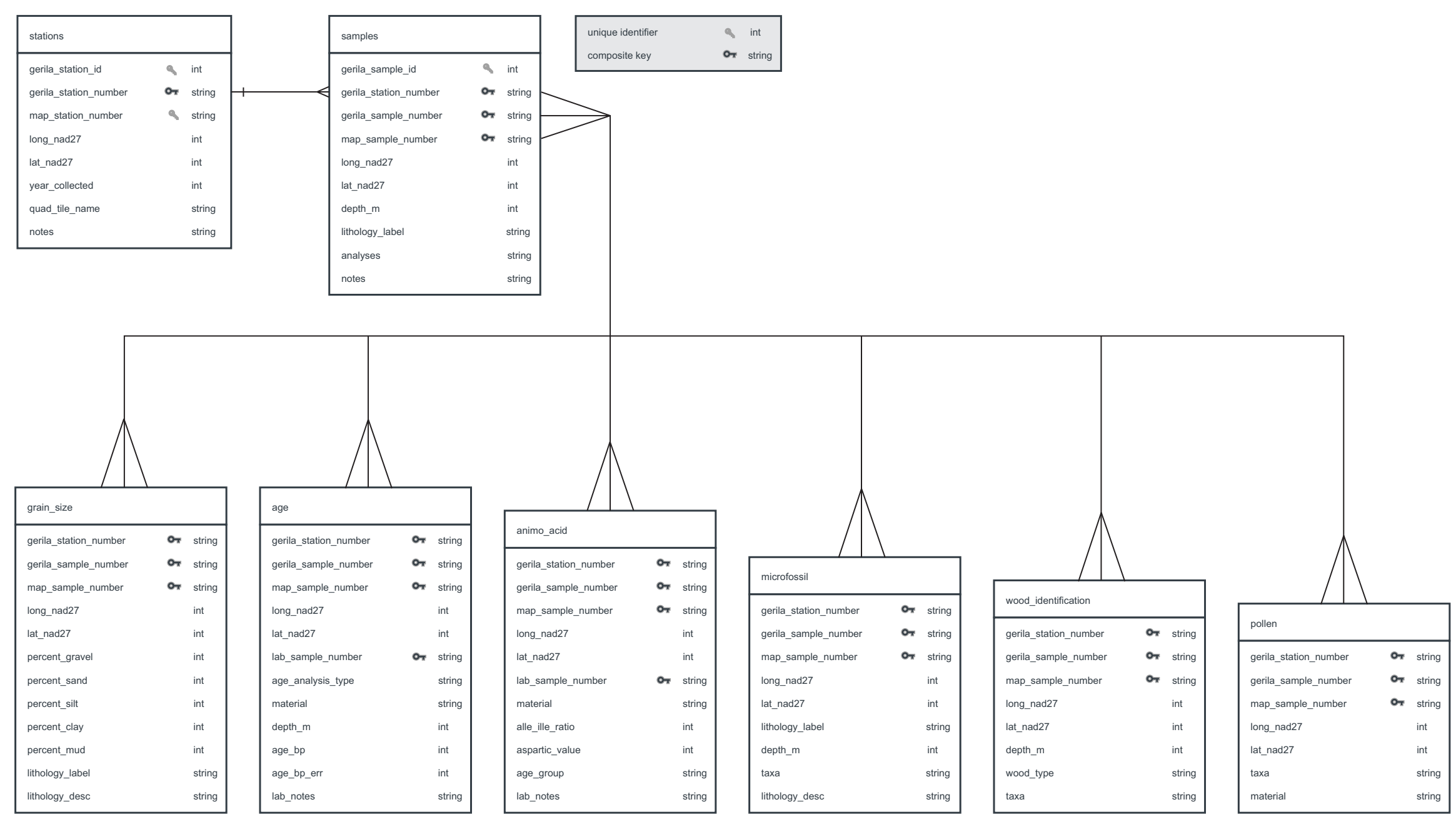

Figure 1. Data relationship diagram. 

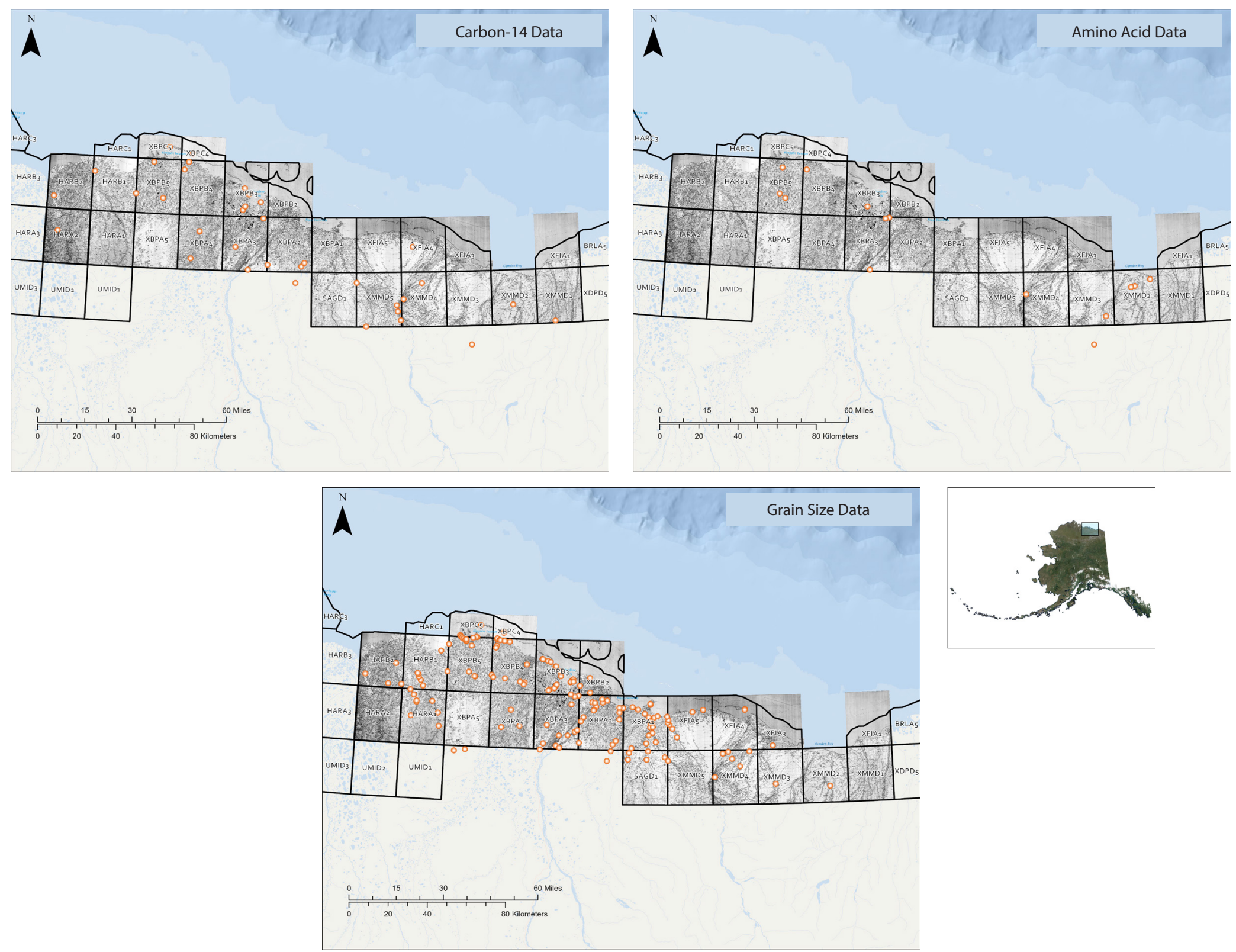

Figure 2. Field station locations of carbon-14, amino acid, and grain size data. 

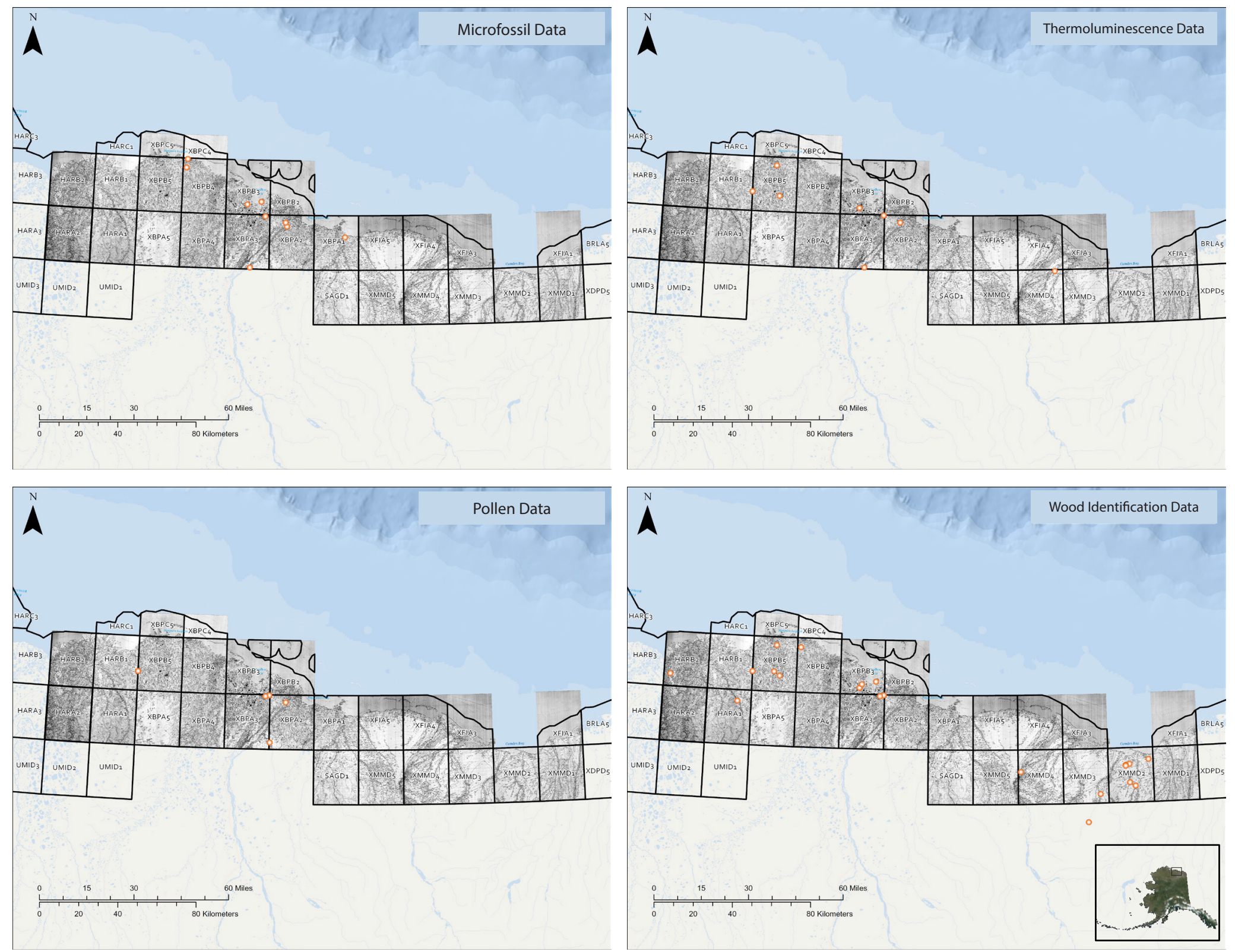

Figure 3. Field station locations of microfossil, thermoluminescence, pollen, and wood identification data. 


\section{REFERENCES CITED}

DGGS Staff, and Papp, K.R., 2005, Alaska GeoSurvey News - A summary of the past, present, and future of distributing Alaskan geologic data in digital format: Alaska Division of Geological \& Geophysical Surveys Newsletter 2005-2, 8 p. https://doi.org/10.14509/14595

Rawlinson, S.E., 1986a, Surficial-geologic map of the Beechey Point A-3 Quadrangle, Alaska: Alaska Division of Geological \& Geophysical Surveys Report of Investigation 86-8, 1 sheet, scale 1:63,360. https://doi.org/10.14509/2407 1986b, Surficial-geologic map of the Beechey Point A-4 Quadrangle, Alaska: Alaska Division of Geological \& Geophysical Surveys Report of Investigation 86-9, 1 sheet, scale 1:63,360. https://doi.org/10.14509/2408

1986c, Surficial-geologic map of the Beechey Point B-2 Quadrangle, Alaska: Alaska Division of Geological \& Geophysical Surveys Report of Investigation 86-10, 1 sheet, scale
1:63,360. https://doi.org/10.14509/2409 1986d, Surficial-geologic map of the Beechey Point B-3 Quadrangle, Alaska: Alaska Division of Geological \& Geophysical Surveys Report of Investigation 86-11, 1 sheet, scale 1:63,360. https://doi.org/10.14509/2410 1986e, Surficial-geologic map of the Beechey Point B-4 Quadrangle, Alaska: Alaska Division of Geological \& Geophysical Surveys Report of Investigation 86-12, 1 sheet, scale 1:63,360. https://doi.org/10.14509/2411 1990, Surficial geology and morphology of the Alaskan central Arctic Coastal Plain: Alaska Division of Geological \& Geophysical Surveys Public Data File 90-27, 326 p., 6 sheets, scale 1:63,360. https://doi.org/10.14509/1461 1993, Surficial geology and morphology of the Alaskan central Arctic Coastal Plain: Alaska Division of Geological \& Geophysical Surveys Report of Investigation 93-1, 172 p., 6 sheets, scale 1:63,360. https://doi.org/10.14509/2484 